\title{
The Effect of Tourist Attraction Toward Visitor Satisfaction in Sindang Barang Cultural Village, Bogor Regency
}

\author{
Maidar Simanihuruk ${ }^{1}$, Adhi Trirachmadi Mumin ${ }^{2}$, Saptarining Wulan ${ }^{3}$ \\ 1 Sekolah Tinggi Pariwisata Bogor \\ 2 Sekolah Tinggi Pariwisata Trisakti \\ ${ }^{3}$ Sekolah Tinggi Pariwisata Trisakti \\ 1 meydar_bj@yahoo.co.id
}

\begin{abstract}
A part of the attraction destination is the cultural tourist attraction that encompasses cultural villages. Bogor Regency has a cultural village that has a variety of Sundanese arts and culture, history and Sundanese beliefs and customs, a natural rural place and has a place to stay or lodging to give a natural impression for tourists who visit. This research was conducted to determine whether tourist attractions affect visitor satisfaction in the Sindang Barang Cultural Village. The purpose of this study was to investigate how much influence the tourist attraction on visitor satisfaction in the Sindang Barang Cultural Village. The Method of research used is quantitative methods in order to obtain more comprehensive, valid, reliable, and objective data. The samples were 107 visitors who came to Sindang Barang Cultural Village. Analysis used descriptive statistical methods, simple correlation coefficient of Pearson, Coefficient of determination and regression analysis. The result showed that tourist attraction had a positive influence of $70 \%$ and there is a significant effect between Tourist Attraction toward Visitor Satisfaction in Sindang Barang Cultural Village.
\end{abstract}

Keywords: Tourist Attraction, Visitor Satisfaction, Cultural Village. 


\section{A. Introduction}

Ajeng (2016) argued that Tourism Products is a tourist attraction package that is not only about the beauty or exoticism of a tourist destination but includes three main components consisting of (1) attraction: natural attraction, cultural attraction and man-made attraction, (2) amenities related to facilities or accommodations, (3) accessibility related to all transportation, distance or ease of reaching tourist destinations, as well as other supporting elements such as local communities, stakeholders and the government. A tourism product must have several aspects such as attractiveness, maintainability, ease of use and in particular a product must satisfy consumer desires and be able to fulfill all consumer expectations of a product (Kotler, 2011:112). Tourism products are places that have attraction as a supporting factor as attracting tourists to visit the tour and have adequate facilities such as access to travel, recreation and many things that make tourists interested in coming to the place. To attract tourists to visit a tourist attraction, tourism objects must have attractive tourist attractions and adequate facilities to support the needs of tourists. Various tourist needs are, among others, transportation facilities, accommodation, travel agencies, attractions (food, recreation, and entertainment), food service, and souvenir items (Pitana \& Gayatri in Hidayat, Rahmanita, \& Hermantoro, 2017). If tourists feel comfortable because the facilities available are adequate and tourism objects are attractive, the expectations of tourists when visiting will be fulfilled when they visit. This will lead to a sense of satisfaction because their expectations are met.

Sindang Barang Cultural Village has the opportunity of three components of tourism products namely attraction, amenities and accessibilities which can attract tourists to be able to come to Sindang Barang Cultural Village. From the component of attraction, there is an attraction from the village that can attract visitors to come to the location. With a typical Sundanese tourist attraction, Sindang Barang Cultural Village should be able to attract the number of visitors with several attractions in the village. The aim of this research is to know the effect of tourist attraction toward visitor satisfaction in Sindang Barang Cultural Village.

\section{B. Literature Review}

1. Tourist Attraction

A Tourist Attraction must meet the conditions for the development of the area (Suryadana and Octavia, 2015:53). These conditions are:

a) What to see

In these places there must be objects and tourist attractions that are different from those owned by other regions. The area must have special 
attractions and cultural attractions that can be used as "entertainment" for tourists. What to see includes natural scenery, activities, arts and tourist attractions

b) What to do

In this place, in addition to many that can be seen and witnessed, activities and recreational facilities must be provided that can make tourists feel at home for a long time

c) What to buy

Tourist destinations should be available for shopping facilities, especially souvenirs and folk handicrafts as souvenirs.

d) What to arrive

This includes accessibility, how visitor can visit the tourist attraction, what vehicles will be used and how long to arrive at the tourist destination.

e) What to stay

How tourists will stay for a while on vacation. They need lodging either star hotels or non-star hotels and so on.

2. Visitor Satisfaction

Visitor Satisfaction is a feeling of pleasure or disappointment that someone appears after comparing the performance of the product that is thought of the performance or expected results. If the performance of a product meets or exceeds expectations of tourists it will create a sense of satisfaction in each tourist, while if the product performance is below expectations, someone will feel dissatisfied and disappointed (Kotler, 2006:70).

Factors of boosting satisfaction:

a) Product Quality

Customers will feel satisfied after buying or using products and services that are in line with expectations of good quality.

b) Price

Usually affordable prices with good product quality will be of greater value to create customer satisfaction

c) Service Quality

To satisfy customers, a company should first improve services that are as maximum as possible given to customers and always evaluate services that have been given directly either by providing product knowledge training to all employees or how to deal with customer complaints correctly. 
d) Easiness

Ease and comfort in reaching tourist destinations can affect customer satisfaction factors.

3. Cultural Village

Cultural Village is a vehicle for a group of people who perform cultural activities that express belief systems (religion), art systems, livelihood systems, technological systems, communication systems, social systems, and environmental systems, spatial planning and architecture by actualizing their potential wealth and conserving them by careful about its cultural wealth, especially those seen in customs and traditions, performing arts, crafts, and spatial and architectural (Culture Office of Yogyakarta Special Region).

\section{Research Methodology Data Collection}

1. Population and Sample

Determination of the sample in this study is the population of tourists visiting the Sindang Barang Bogor Cultural Village. Dissemination of the large sample, researchers distributed questionnaires using the help of the Google Docs application. Based on the calculation of the Slovin formula results obtained $n=$ 99.84 and rounded to 100. The results of the deployment using the help of the Google Docs application, obtained the final result is 107 respondents. Questionnaires were distributed to 107 respondents utilizing non-probability sampling of purposive sampling technique that allows the researcher to not giving equal opportunities to all elements of the population to be selected as a respondent. Purposive sampling is a technique to determine a sample of research with a number of specific considerations that aim so that the data obtained later can be more representative (Sugiyono: 2008 ). Data collection was held from December 2017 to July 24th, 2018, and they were required to cross as the response of which best described their level of agreement within each of the questionnaire items. Of these, 107 responses were deemed useful and used in the data analysis with a valid response rate of 90 percent. Their participation was voluntary and thus leads to no response bias.

\section{Instruments}

The structured close-ended questionnaire was designed on the basis of the objectives of this study. The first part of the three-section questionnaire contained general demographic questions, relating to such matters as gender and age, while the second part comprised questions about the respondents response about special and cultural attraction that are seen and witnessed, activities, facilities and accessibility. The final part of the questionnaire contained questions on satisfaction of the visitor. Each indicator construct various questions that suit 
the context of the research (i.e. what to see (3), what to do (1), what to buy (1), what to stay (2), what to arrive (1), hospitality (2) and visitor satisfaction (12) and requires the respondents to rate their degree of agreement with the propositions in the survey. This instrument was adopted from literature research conducted by Ajeng Fitri (2016) and measured on a five -point Likert scale ranging from 1 (strongly disagree) to 5 (strongly agree) using multi-item scales.

\section{Data Analysis}

The completed and structured close-ended questionnaires were coded and keyed in Statistical Package for Social Sciences (SPSS) computer program version 22 and descriptive analysis such as means, standard deviation, and correlation analysis were performed. Next, further investigation using hierarchical regression analysis was executed to assess the relationship between a set of independent variables and the dependent variable, controlling the effect of a different set of independent variables (i.e. what to see, what to do, what to buy, what to stay, what to arrive, and hospitality) on the dependent variable (i.e. visitor satisfaction), which thereafter could furnish empirical findings in supporting the outlined research objectives.

Table 1 Socio-Demographic Profiles of Respondents

\begin{tabular}{cccc}
\hline Variables & Variables & Frequency & $\mathbf{\%}$ \\
\hline Gender & Male & 48 & 44.9 \\
& Female & 59 & 55.1 \\
\hline Age & $14-19$ & 9 & 8.4 \\
& $20-25$ & 78 & 72.9 \\
& $26-34$ & 9 & 8.4 \\
& $35-43$ & 11 & 10.3 \\
\hline Residential Area & Bogor & 81 & 75.7 \\
& Bandung & 1 & .9 \\
& Jakarta & 12 & 11.2 \\
& Depok & 3 & 2.8 \\
& Sukabumi & 2 & 1.9 \\
& Others & 8 & 7.5 \\
Education & & 42 & 39.3 \\
& Senior High School & 30 & 28.0 \\
& Diploma/Academic & 29 & 27.1 \\
& S1 (Bachelor) & 6 & 5.6 \\
\hline Occupation & S2/S3 (Postgraduate) & 51 & 47.7 \\
& Student & 35 & 32.7 \\
& Employee & 1 & .9 \\
& Government Employee & 9 & 8.4 \\
& Entrepreneur & 11 & 10.3 \\
\hline & Others & &
\end{tabular}




\begin{tabular}{cccc}
\hline Variables & Variables & Frequency & $\mathbf{\%}$ \\
\hline Monthly Income & < IDR 1000000 & 33 & 30.8 \\
& IDR 1000000 - 3000000 & 22 & 20.6 \\
& IDR 3000000 - 5000000 & 35 & 32.7 \\
& $>$ IDR 5000000 & 17 & 15.9 \\
\hline Frequency of Visit & $1-2$ & 86 & 80.4 \\
& $3-4$ & 13 & 12.1 \\
& $5-6$ & 2 & 1.9 \\
& $>6$ & 6 & 5.6 \\
\hline Choosing & Diversity of Tourist Attractions & 56 & 52.3 \\
Considerations & Services provided & 8 & 7.5 \\
& Easy to reach location & 16 & 15.0 \\
& Ticket Prices / Discounts & 3 & 2.8 \\
& Place Comfort & 14 & 13.1 \\
Source of & Others & 10 & 9.3 \\
\hline Information & Social Media/Advertising/ Brochure & 17 & 15.9 \\
& Oamily / Couples Member & 49 & 45.8 \\
& Friends / Relatives & 11 & 28.0 \\
& Relaxation & 45 & 42.3 \\
\hline \multirow{2}{*}{ Motivation } & Nostalgia & 5 & 4.7 \\
& Education & 43 & 40.2 \\
& Others & 14 & 13.1 \\
\hline
\end{tabular}

\section{Results}

\section{Socio-demographic profile of respondents}

Table 1 depicts the respondentse socio-demographic profile. Male respondents made up 44.9 percent of the sample while females made up 55.1 percent. The respondents who come to Sindang Barang Culture Village are dominated aged $20-25$ years (72.9 percent) because of young age who have a lot of free time to walk compared to the adult age (usually have a permanent job). This was followed by 47.7 percent of them are students and the young employee made up 32.7 percent. The majority of respondents (75,5 percent) come from Bogor and respondents (80.4 percent) specified that they have been visit at Sindang Barang Culture Village 1-2 times a year. This was followed by 12.1 percent of them who only visit 3-4 times a year. For monthly income 32.7 percent of the respondents are employees who have revenue IDR $3-5$ million and 30.8 percent respondents are students who spent less than IDR 1 million per month. For choosing considerations, respondents made up 52.3 percent because of the diversity of tourist attractions at Sindang Barang Culture Village and they get information about the Sindang Barang Culture Village made up 45.8 percent are obtained from friends / relatives at $45.8 \%$ and these number of respondents who are young, where the youth is a time of group life, togetherness, and friendship 
provides new information, it seems that there is a Sindang Barang Culture Village. For their motivation to come to Sindang Barang Cultural Village for 42.1 percent relaxation purposes are employees. Relaxation for a number of employees to calm down, enjoy the beauty of nature, find a new place that is more comfortable, and do new activities that create peace in the Sindang Barang Cultural Village. Meanwhile, many respondents who come to the Sindang Barang Cultural Village also aim to educate with the results of 40.2 percent due to the large number of students and students who wish to learn about Sundanese culture.

\section{Reliability analysis}

Reliability testing is a tool to measure a questionnaire which is an indicator of variables or constructs. A questionnaire is said to be reliable or reliable if someone's answer to the statement is consistent or stable over time (Ghozali, 2013: 47). Instrument reliability is needed to obtain data in accordance with measurement objectives. To achieve this, a reliability test was performed using SPSS 22 with the Cronbach's alpha model. A construct is said to be reliable if the value of Cronbach's alpha is $>0.60$. The reading of Cronbach ${ }^{\text {ee }} \alpha$ for all the variables as described in Table 2 exceeds the criterion of 0.60 , indicating the survey instrument is reliable to measure all constructs consistently and is free from random error.

Table 2 Reliability Analysis

\section{Reliability Statistics}

\begin{tabular}{rr}
\hline Cronbach's Alpha & N of Items \\
\hline .849 & 10 \\
\hline
\end{tabular}

\section{Descriptive statistics}

The descriptive statistics for Respondents' Response of The Effect of Tourist Attraction Toward Visitor Satisfaction in Sindang Barang Cultural Village, Bogor Regency is presented in Table 3.

Table 3 Respondents' Response of The Effect of Tourist Attraction Toward Visitor's Satisfaction

\begin{tabular}{llll}
\hline \multicolumn{1}{c}{ Items } & Labels & Means & SD \\
\hline Have natural scenery beautiful & WS1 & 4.16 & .870 \\
\hline $\begin{array}{l}\text { Having learning activities and } \\
\text { know Sundanese art }\end{array}$ & WS2 & 4.28 & .775 \\
$\begin{array}{l}\text { Unique and unique Attractions WS3 } \\
\text { Tradition Rituals Sunda, Serentaun }\end{array}$ & WS3 & 4.18 & .799 \\
$\begin{array}{l}\text { Have activities and facilities } \\
\text { recreation }\end{array}$ & WD1 & 3.91 & .807 \\
\hline
\end{tabular}




\begin{tabular}{|c|c|c|c|}
\hline Items & Labels & Means & SD \\
\hline $\begin{array}{l}\text { Have facilities for shop for } \\
\text { souvenirs and items folk crafts }\end{array}$ & WB1 & 3.63 & .937 \\
\hline Have lodging & WS1 & 3.87 & .814 \\
\hline Adequate infrastructure and facilities & WS2 & 3.56 & .838 \\
\hline Easiness Access to locations & WA1 & 3.19 & .963 \\
\hline Security guaranteed & HO1 & 3.74 & .862 \\
\hline $\begin{array}{l}\text { Society and employees friendly } \\
\text { and polite }\end{array}$ & $\mathrm{HO} 2$ & 4.08 & .881 \\
\hline $\begin{array}{l}\text { Satisfaction on Tourist Attractions } \\
\text { at Sindang Barang Cultural Village }\end{array}$ & CS1 & 4.07 & .768 \\
\hline $\begin{array}{l}\text { Satisfaction with Accessibility } \\
\text { towards tourist sites }\end{array}$ & CS2 & 3.36 & .934 \\
\hline $\begin{array}{l}\text { Satisfaction with the facilities } \\
\text { in Sindang Barang }\end{array}$ & CS3 & 3.75 & .859 \\
\hline Price of admission & CS4 & 3.64 & .756 \\
\hline Promotion of Promo Prices/Discount & CS5 & 3.82 & .969 \\
\hline Alertness to serve traveler & CS6 & 3.79 & .855 \\
\hline $\begin{array}{l}\text { Good communicate and explain } \\
\text { information to tourist }\end{array}$ & CS7 & 3.95 & .745 \\
\hline $\begin{array}{l}\text { Accuracy and suitability time } \\
\text { in tourist attractions }\end{array}$ & CS8 & 3.73 & .784 \\
\hline Handling Complaint & CS9 & 3.74 & .839 \\
\hline $\begin{array}{l}\text { Have knowledge about all } \\
\text { tourist attractions }\end{array}$ & CS10 & 3.85 & .867 \\
\hline $\begin{array}{l}\text { Have hospitality and politeness } \\
\text { in serving visitor }\end{array}$ & CS11 & 4.03 & .783 \\
\hline Willingness to help & CS12 & 3.93 & .839 \\
\hline $\begin{array}{l}\text { Ease of reaching all tourist attractions } \\
\text { all tourist attractions }\end{array}$ & CS13 & 3.92 & .814 \\
\hline
\end{tabular}

The multi-item statements are designed on a five-point Likert scale ranging from 1 (strongly disagree) to 5 (strongly agree). 
Based on Table 3, the highest mean value is on WS2 indicator statement which is at an average of 4.28 which means that respondents agree that Sindang Barang Cultural Village has learning activities and recognizes Sundanese Cultural Arts (learning the history of Indigenous Village, learning farming, learning to dance and learning to play traditional musical instruments). Whereas the lowest mean value is on the statement of tourist attraction statement WA1 which is at an average of 3.19, which means that neutral respondents state that access to the location to the Sindang Barang Cultural Village is easy. Overall respondents' perceptions of Tourist Attraction in Sindang Barang Cultural Village found that the dominant respondents agreed that meant that tourist attraction in Sindang Barang Cultural Village had special attractions and cultural attractions that could be seen and witnessed, lodging like home stay and Hospitality from employees and the community who are friendly and polite. For Visitor Satisfaction, the highest mean value is in the indicator of the statement of CS1, which is on average 4.07, which means that respondents almost all agree that they are satisfied with Tourist Attractions in Sindang Barang Cultural Village. While the lowest mean value is in the indicator of the statement of CS2 which is at an average of 3.36 which means that neutral respondents expressed satisfaction with access to the location to the Goods Session Culture Village. Respondents' perceptions of Visitor Satisfaction in Sindang Barang Cultural Village found that the dominant respondents agreed that meant that the tourists who had visited were satisfied with the quality of tourism products, prices, quality of service and ease in reaching all tourist attractions provided in Kampung Sindang Barang Culture Village.

\section{Discussion}

Simple Correlation Analysis is used to determine the relationship between one independent variable to the dependent variable. Determination analysis in simple regression is used to determine the percentage contribution of the influence of the independent variable on the dependent variable (Sugiyono, 2016:101).

Table 4 Result of Calculation of the Influence Correlation Coefficient Variable Independent Towards Variable Dependent

\begin{tabular}{l|l|r|r|r}
\hline & & Model Summary \\
\hline Model & $\mathrm{R}$ & R Square & $\begin{array}{c}\text { Adjusted R } \\
\text { Square }\end{array}$ & $\begin{array}{c}\text { Std. Error of } \\
\text { the } \\
\text { Estimate }\end{array}$ \\
\hline 1 & $.837^{\text {a }}$ & .700 & .697 & 4.256 \\
\hline a. Predictors: (Constant), Tourist Attraction
\end{tabular}
b. Dependent Variable: Visitor Satisfaction


Based on table 4 , the $\mathrm{R}$ number is 0.837 . This shows that there is a very strong relationship between Tourist Attraction and Visitor Satisfaction. The Determination Coefficient is obtained by R2 ( $\mathrm{R}$ Square) by $0.700(70.0 \%)$. This shows that the percentage contribution of the influence of independent variables Tourist Attraction and Tourism Facilities to the dependent variable Visitor Satisfaction by $70 \%$ while $30 \%$ is influenced by other variables not examined.

Table 5 Coefficients ${ }^{\mathrm{a}}$

\begin{tabular}{|c|c|c|c|c|c|c|}
\hline \multirow[b]{3}{*}{ Model } & \multicolumn{4}{|c|}{ UnstandardizedStandardized } & \multirow{2}{*}{\multicolumn{2}{|c|}{$\begin{array}{c}\text { Collinearity } \\
\text { Statistics }\end{array}$}} \\
\hline & \multirow{2}{*}{\multicolumn{2}{|c|}{$\begin{array}{r}\text { Coefficients } \\
\text { Std. }\end{array}$}} & \multicolumn{2}{|c|}{ Coefficients } & & \\
\hline & & & Beta & $\mathrm{t}$ & Sig. Tolera & e VIF \\
\hline 1 (Constant) & 4.809 & 2.88 & & 1.665 & .099 & \\
\hline Daya Tarik Wisata & 1.160 & .074 & .837 & 15.658 & 0001.000 & 1.000 \\
\hline
\end{tabular}

Seen in Table 5 there is a sig value of 0.000 . The sig value is smaller than the probability value 0.05 or the value $0.000<0.05$, then $\mathrm{H}_{1}$ is accepted and $\mathrm{H}_{0}$ is rejected. The variable independent has tcount of 15.658 with table is $\mathrm{n}-\mathrm{k}=107-3$ $=104$, table $=1.659$. So, tcount $>$ ttable is $15.658>1.659$, it can be concluded that the independent variable has a contribution, positive and has a direct relationship to dependent.. So it can be concluded that the tourist attraction has a significant influence on visitor satisfaction. Figure 1 exhibits the normal probability plot (PP) while Figure 2 illustrates the scatter plot of the model where no major deviations from norms exist, with most of the scores rectangularly distributed in the centre.

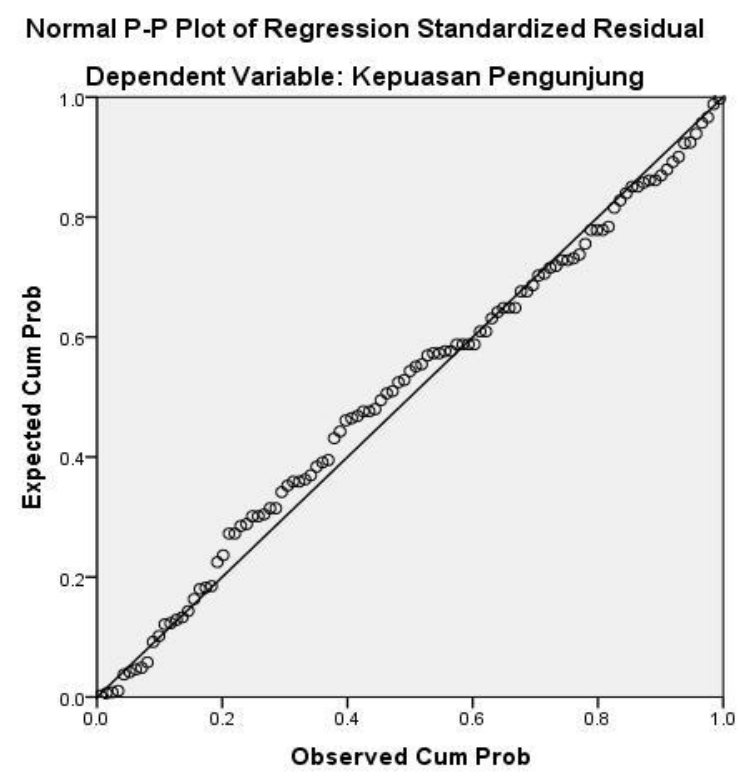

Figure 1. Normal $P-P$ Plot 


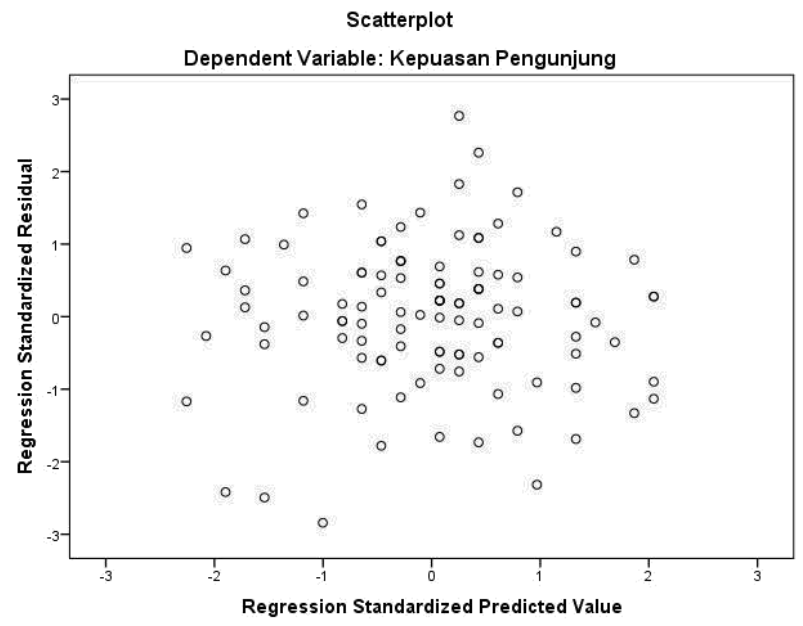

Figure 2. Scatter Plot

From the P-P Plot Test in figure 1 and figure 2, it can be seen that the points spread around the diagonal line, and the spread is in the direction of the diagonal line. So that it can be said that the data is normally distributed.

\section{E. Conclusion and Recommendations}

The results of this study offer a new perception of the findings on earlier studies that could be of interest to researchers To develop further research, it is hoped that other studies will add to the variables studied in order to complete and explore the content of visitors, in addition to distributing questionnaires, it is expected that in subsequent research it will also be equipped with interview methods so that the results can be more accurate. Based on empirical analysis of simple regression result, the conclusion of this research are the percentage contribution of the influence of independent variables Tourist Attraction to the dependent variable Visitor Satisfaction by $70 \%$ while 30\% influenced by other variables not examined. Recommendation based on the study of data and background of the problems proposed by the researcher as evaluation material aimed at the research object, as follows:

(1) The variable tourist attraction in Cultural Village has a dominant influence in influencing visitor satisfaction by having the uniqueness and characteristics of Sunda 'Tradition Ritual Tourist Attraction which is the hallmark of Sindang Barang Cultural Village, it is necessary for the management to still maintain this tourist attraction with regular return held every year.

(2) The continuity of tourist attractions, especially Sundanese traditional attractions Serentaun needs to receive support and attention from the Bogor Regency Government, especially the Bogor Regency Culture and Tourism Office because it relates to attention to the preservation of Sundanese culture. 


\section{REFERENCES}

Ajeng, Fitri Nurlestari. (2016). Pengaruh Daya Tarik Wisata Terhadap Niat Kunjungan Ulang Wisatawan Dengan Kepuasan Wisatawan Sebagai Variabel Interveni8ng Pada Taman Safari Indonesia Cisarua Bogor. Jurnal Pariwisata

Hidayat, Angger., Myrza Rahmanita., and Henky Hermantoro. (2017). Community Empowerment in Plempoh Cultural Tourism Village. Tourism Research Journal. Vol. 1, No. 1: 98 - 116.

Ghozali, Imam. (2013). Aplikasi Analisis Multivariate dengan Program IBM SPSS 21 Update PLS Regresi. Semarang: Badan Penerbit Universitas Diponegoro.

Kotler, P. (2006). Managament Pemasaran Edisi 11. PT. Indeks: Jakarta . (2011). Marketing For Hospitality and Tourism. Pearson Education: New Jersey

Suryadana, Liga M. \& Vanny Octavia. (2015). Pengantar Pemasaran Pariwisata. Alfabeta Cv: Bandung

Sugiono. (2008). Metode Penelitian Kuantitatif Kualitatif dan R\&D. Alfabeta: Bandung

.(2016). Metode Penelitian Manajemen (Pendekatan Kuantitatif, Kualitatif, Kombinasi (Mixed Methods), Penelitian Tindakan (Action Researcb), dan Penelitian Evaluasi). Bandung: Alfabeta $\mathrm{Cv}$ 